\title{
Outcomes of Patients with Definitive Diagnosis of Influenza A (H1N1) Virus Infection Admitted to Affiliated Hospitals of Babol University of Medical Sciences, 2015 - 2016
}

\author{
Soheil Ebrahimpour ${ }^{1}$, Arefeh Babazadeh르, Mahmoud Sadeghi-Haddad-Zavareh"1, \\ Masomeh Bayani ${ }^{1}$, Veneela Krishna Rekha Vasigala ${ }^{2}$, Mostafa Javanian ${ }^{1}$ \\ ${ }^{1}$ Infectious Diseases and Tropical Medicine Research Center, Health Research Institute, Babol University of \\ Medical Sciences, Babol, Iran \\ ${ }^{2}$ Rangaraya Medical College, NTR University of Health Sciences, Kakinada, India
}

\section{SUMMARY}

With the aim to analyze the clinical manifestations and outcomes of influenza, we evaluated the symptoms of proven H1N1 cases and outcomes of patients admitted to hospitals Babol University of Medical Sciences during 2015 - 2016.

In this descriptive cross-sectional study, we included patients diagnosed with influenza-like illness (ILI) from October 2015 to March 2016 at hospitals affiliated to Babol University of Medical Sciences.To diagnose H1N1 infection, reverse transcription-polymerase chain reaction (RT-PCR) was performed on nasopharyngmeal swabs collected from the patients.

In the current study, 123 patients were admitted due to ILI.The RT-PCR result was positive in $47.2 \%$ of patients. Symptoms such as productive cough $(35.3 \%)$, sore throat $(51.4 \%)$, headache $(50 \%)$, dyspnea $(53.2 \%)$ were comparable between PCR + H1N1 confirmed cases and H1N1 negative cases. Among the H1N1 confirmed cases, $48.3 \%$ were admitted to the intensive care unit (ICU) because of the disease severity, and $20.7 \%$ died even after receiving the therapy for several days. Among the infected cases, 20 women were pregnant, out of which three subjects died. Mortality was mostly observed in the age $>50(39 \%)(p=0.03)$. Myalgia was significantly less observed in the group with mortality compared to other age groups $(6.5 \% \mathrm{vs.} 93.5 \%)(p=0.005)$. The mortality rate of patients who received vancomycin was found to be significantly low $(40 \%)(p=0.01)$. In mortality group, the frequency of patients with creatinine levels $>1.5 \mathrm{mg} / \mathrm{dL}$ was significantly higher $(58.3 \%)(p=0.009)$ than in the group of patients who recovered. The average length of hospitalization in the mortality group was significantly longer than the hospitalization of the recovered group (11.1 days vs. 6.3 days) $(p=0.02)$.

The current study reported a mortality rate that was more than expected in comparison to previous seasons. Our study results suggest that the absence of typical influenza symptoms such as myalgia should not cause a 
Original article

delay in the diagnosis of this infection in cold seasons.

Key words: influenza A (H1N1), outcome, reverse transcription-polymerase chain reaction

Corresponding author:

Mostafa Javanian

E-mail: dr.javanian1@yahoo.com 


\section{INTRODUCTION}

Influenza viruses are categorized into three types (A, B and C), among which the type A influenza is the most prevalent and virulent human pathogen. Type $\mathrm{A}$ influenza can further be differentiated into several types based on the type of surface hemagglutinin (HA) and neuraminidase (NA) $(1,2)$. Every year, respiratory infections with these viruses are reported in cold seasons and they infect 5 to 15 percent of the world population (3). During the peak periods of seasonal influenza, most of the hospitalizations occur in children under the age of 2 and adults over 65 years (4). Typically, over 90\% of deaths are seen in elderly patients with underlying diseases such as diabetes, heart disease, pulmonary, and neurological diseases $(4,5)$.

Pandemic influenza A H1N1 (pH1N1) virus contains a combination of gene segments that were not seen in humans and animals before 2009. This type of influenza virus is one of the different types of influenza A virus that, like all other influenza cases, is transmitted through coughing, sneezing, and contact with the infected objects. The incubation period for the virus is approximately 2 - 7 days (6). The infection usually affects the young and middle-aged people. Infected patients present symptoms such as sudden onset of fever, chills, sore throat, headaches, malaise, dry cough, and sometimes gastrointestinal symptoms such as diarrhea, nausea, and vomiting $(7,8)$. H1N1 infleuenza pandemic first occurred in 2009 in the USA. As per the Centers for Disease Control and Prevention (CDC) estimates, the global death toll in 2009 was estimated as more than 284,000 (9) cases. Since then, infection with this virus has spread and has been reported in 191 countries (10). The first case of H1N1 infection in Iran was reported on June 22,2009 . Since then, 2,662 proven cases were reported in 2010 with $75 \%$ of them in the age range of 5 to 40 years old (11). After 2010, some cases of severe influenza (proven cases of H1N1) as part of seasonal influenza are reported each year. In winter of 2015, a lot of youngaged individuals were hospitalized with a probable prognosis of influenza and later confirmed as influenzalike illness (ILI). A high mortality rate due to the infection was observed during the winter season of 2015. Therefore, we performed this retrospective study to understand the exact symptoms of H1N1 influenza as well as its related mortality and morbidity of patients admitted to hospitals of Babol University of Medical Sciences during the flu season from October 2015 to March 2016.

\section{METHODS}

In this descriptive cross-sectional study on the patients diagnosed with ILI from October of 2015 to March 2016 in hospitals affiliated to Babol University of Medical Sciences, nasopharyngeal swabs were taken and sent to the reference laboratory for reverse transcription-polymerase chain reaction (RT-PCR). Patient's background information, clinical and laboratory findings, and the outcome of the treatment were filled in some questionnaires. The Ethics Committee of Babol University of Medical Sciences has approved the research. Proven cases of H1N1 infection based on the positive PCR results were compared among the dead and recovered patients for clinical symptoms and laboratory results using SPSS 16 statistical software. P-value $\leq 0.05$ was considered statistically significant.

\section{RESULTS}

A retrospective study on the outcome of patients hospitalized due to ILI was conducted on a total of 123 patients hospitalized during the flu season between October of 2015 and March 2016. Patient samples were collected using swabs from nasopharyngeal secretions and examined by RT-PCR for H1N1 influenza in the reference laboratory. The majority of the patients experienced symptoms such as fever (78\%), cough (65.9\%), and chills (58.5\%).

RT-PCR results were positive in 58 patients $(47.2 \%)$, and many of them were aged above 50 (25 out of 58 ) and females (37 out of 58). $64.2 \%$ of the patients were females, and the majority of them were aged over 50 (43.1\%). The difference between clinical and laboratory symptoms of PCR+ and PCR- patients was not significant since patients categorized into both these groups experienced common symptoms such as fever, cough, sore throat, headache, and rhinnorea (Table 1). Few patients did experience clinical symptoms such as chest pain (a total of 18 patients) and diarrhea (a total of 7 patients), among which many (12 out of 18 chest pain patients, 5 out of 7 diarrhea patients) were diagnosed positive for ILI in PCR (Table 1).

Among the 58 PCR+patients, 28 cases (48.3\%) were admitted to the intensive care unit (ICU) and underwent mechanical ventilation. After receiving care in ICU, a total of 16 patients recovered and the other 12 patients never showed any improvement and ultimately died. Among the 58 PCR+ cases, 20 were pregnant 
Table 1. Clinical characteristics of the patients with confirmed and suspected H1N1 infection

\begin{tabular}{ccc}
\hline \hline Variable & PCR $^{+}$ & PCR- \\
\hline Fever (\%) & $44(45.8 \%)$ & $52(54.2 \%)$ \\
Chills (\%) & $30(41.7 \%)$ & $42(58.3 \%)$ \\
Myalgia (\%) & $31(44.9 \%)$ & $38(55.1 \%)$ \\
Headache (\%) & $20(50 \%)$ & $20(50 \%)$ \\
Cough (\%) & $33(40.7 \%)$ & $48(59.3 \%)$ \\
Sore throat (\%) & $19(51.4 \%)$ & $18(48.6 \%)$ \\
Productive cough (\%) & $18(35.3 \%)$ & $33(64.7 \%)$ \\
Chest pain (\%) & $12(66.7 \%)$ & $6(33.3 \%)$ \\
Dyspnea (\%) & $33(53.2 \%)$ & $29(46.8 \%)$ \\
Rhinorrhea (\%) & $12(48 \%)$ & $13(52 \%)$ \\
Diarrhea (\%) & $5(71.4 \%)$ & $2(28.6 \%)$ \\
\hline \hline
\end{tabular}

Table 2. Clinical characteristics of the patients with mortality compared with proven H1N1 cases

\begin{tabular}{cccc}
\hline \hline Variable & Dead & Alive & P-value \\
\hline Fever (\%) & $9(20.5 \%)$ & $35(79.5 \%)$ & 0.6 \\
Chills (\%) & $5(16.7 \%)$ & $25(83.3 \%)$ & 0.3 \\
Myalgia (\%) & $2(6.5 \%)$ & $29(93.5 \%)$ & 0.005 \\
Headache (\%) & $3(15 \%)$ & $17(85 \%)$ & 0.3 \\
Cough (\%) & $5(15.2 \%)$ & $28(84.8 \%)$ & 0.2 \\
Sore throat (\%) & $2(10.5 \%)$ & $17(89.5 \%)$ & 0.1 \\
Productive cough (\%) & $2(11.1 \%)$ & $16(88.9 \%)$ & 0.2 \\
Chest pain (\%) & $3(25 \%)$ & $9(75 \%)$ & 0.4 \\
Dyspnea (\%) & $9(27.3 \%)$ & $24(72.7 \%)$ & 0.1 \\
Rhinorrhea (\%) & $5(41.7 \%)$ & $7(58.3 \%)$ & 0.06 \\
Diarrhea (\%) & $1(20 \%)$ & $4(80 \%)$ & 0.7 \\
\hline \hline
\end{tabular}

women, out of which three women deceased. The reported mortality rate for men was $22.7 \%$. Most of the mortality was in the age group over $50(39 \%)(p=0.03)$.

There was not any significant difference between the mortality and the improved groups in clinical cases such as a headache, sore throat, fever, chills, productive cough, dyspnea, and gastrointestinal symptoms. However, myalgia was significantly less observed in the deceased patients in comparison to the patients who recovered from ILI (6.5\% vs. 93.5\%) $(p=0.005)$ (Table 2). The presence of diabetes and underlying lung diseases did not have a significant effect on mortality. Oseltamivir was used as a treatment of choice for the majority of patients (>90\%). In addition to oseltamivir, some patients also received other medications such as ceftriaxone, clindamycin, tavanex, ciprofloxacin, and clarithromycin. However, the choice of one medication over other medications did not have a significant effect on reducing the mortality. However, the mortality rate of patients who received vancomycin was significantly lower $(40 \%)(p=0.01)$. Corticosteroids were prescribed to only three patients $(25 \%)$, but all these patients died eventually.

Evaluation of the laboratory findings for white blood cell (WBC) count, haemoglobin ( $\mathrm{Hb})$, erythrocyte sedimentation rate (ESR), C-reactive protein (CRP), alanine aminotransferase (ALT), and sodium levels resulted in no significant difference between the patients who died and those who recovered (Table 3).

Thrombocytopenia was reported in $41.7 \%$ of the deceased and $34.1 \%$ of the recovered patients. Leukocytosis was reported in the deceased and recovered group at $31.6 \%$ and $68.4 \%$, respectively. In the mortality group, $50 \%$ of the subjects had an erythrocyte sedimentation rate $(\mathrm{ESR})>30 \mathrm{~mm} / \mathrm{hr}, 33.3 \%$ had Creactive protein (CRP) $>50 \mathrm{mg} / \mathrm{L}$ and $40 \%$ had alanine 
aminotransferase (ALT) $>40 \mathrm{U} / \mathrm{L}$, although none of these levels were statistically significant for the levels noticed in the recovered patients. The major significant difference between the deceased and recovered patients with respect to the laboratory results is the creatine $(\mathrm{Cr})$ levels. $\mathrm{Cr}$ levels are significantly higher in the deceased patients with the level of $\mathrm{Cr}$ exceeding $1.5 \mathrm{mg} / \mathrm{dL}$ in
$58.3 \%$ (7 out of 12$)$ of the deceased patients as opposed to $17.7 \%$ ( 8 out of 45 ) of the recovered patients ( $p=$ 0.009). Considering the number of days that patients spend in the hospital, the average length of hospitalization in the mortality group was significantly higher than in the recovered group (11.1 days vs. 6.3 days) $(p=$ $0.02)$.

Table 3. Paraclinical features of the patients with mortality compared with proven H1N1 cases

\begin{tabular}{ccccc}
\hline & Variable & Dead & Alive & P-value \\
\hline WBC (\%) & $4000<$ & 0 & $5(100 \%)$ & 0.2 \\
& $4000-10000$ & $6(18.2 \%)$ & $27(81.7 \%)$ & 0.3 \\
Hb (\%) & $10000>$ & $6(31.6 \%)$ & $13(68.4 \%)$ & \\
ESR (\%) & $10 \leq$ & $6(28.6 \%)$ & $15(71.4 \%)$ & 0.4 \\
& $10>$ & $6(16.7 \%)$ & $30(83.3 \%)$ & 1 \\
CRP (\%) & $30 \leq$ & $5(16.1 \%)$ & $26(83.9 \%)$ & \\
& $30>$ & $5(25 \%)$ & $15(75 \%)$ & 0.009 \\
Cr (\%) & $10 \leq$ & $1(16.7 \%)$ & $5(83.3 \%)$ & 1 \\
ALT (\%) & $11-50$ & $5(25 \%)$ & $15(75 \%)$ & $12(80 \%)$ \\
& $51>$ & $3(20 \%)$ & $37(88.1 \%)$ & \\
Na (\%) & $1.5<$ & $5(11.9 \%)$ & $8(53.3 \%)$ & \\
& $1.5 \geq$ & $7(46.7 \%)$ & $21(77.8 \%)$ & 0.4 \\
PT (\%) & $40 \leq$ & $6(22.2 \%)$ & $12(75 \%)$ & \\
& $40>$ & $4(25 \%)$ & $4(66.7 \%)$ & 0.3 \\
\hline \hline
\end{tabular}

\section{DISCUSSION}

The current study estimated that the mortality rate among patients with a definite diagnosis of H1N1 infection is $20.7 \%$, which is comparable to the results of other studies in China, Brazil and the United Kingdom with the estimated mortality rates of $17.4 \%, 28.8 \%$, and $30.2 \%$, respectively) (12). The signs and symptoms of H1N1 inflenza can become severe as $48.3 \%$ of the H1N1 diagnosed patients were admitted in ICU and underwent mechanical ventilation. Regarding H1N1 influenza as one of the agent strains of seasonal influenza, it was slightly higher than expected and this is one of the issues that discusses the occurrence of slight drift changes in strains of H1N1 influenza. Genetic drift can lead to the emergence of new strains that cause more mortality and morbidity because of the low immunity level of community to these new strains. Most patients with the confirmed H1N1 infection belong to the age group over 50 (43.1\%) followed by the age group of 21 $50(32.6 \%)$ years. Mortality due to H1N1 infection was also higher in patients aged above 50 (39\%), followed by the patients aged from 20 - 35 (14.3\%) years, which was similar to studies on pandemic H1N1 influenza $(13,14)$. As in pandemic cases, our study suggested that the two groups were at the highest risk: old people due to a weakened immune system as well as younger people whose body does not have the required immunity to the re-emergence of strains since they were not exposed to previous strains (15).

The observations regarding the clinical symptoms between the dead and the recovered patients did not show any apparent differences with the exception of myalgia which was significantly lower in the mortality group patients. Similarly, in some other studies, the severity of fever was taken as a marker for disease severity (16). 
The observation of low myalgia in patients from the mortality group can be due to bias resulting from non-recording of this particular patient symptom in severe cases due to fast progression and more disability during the admission. In the present study, comorbidities such as diabetes and underlying pulmonary diseases did not have a significant effect on the increase in mortality. However, the presence of diabetes was reported as a mortality risk factor in some studies from China (17). In other studies, obesity and asthma were also reported as risk factors for this kind of infection (18).

In our study, receiving vancomycin was associated with lower mortality, which can be a sign of a possible Staphylococcus pneumonia along with influenza pneumonia (19). This relationship has been mentioned in different texts. In the investigation of laboratory findings between the two groups, $58.3 \%$ of mortality patients had increases of creatinine in their test results, which was significantly higher than the improved group. The increase in the levels of creatine in mortality patients group was probably because of the progression of the disease toward organ failure. The average length of hospitalization was significantly higher in the group with mortality as they were admitted to ICU and underwent mechanical ventilation. Due to the low number of confirmed positive H1N1 infections and the retrospective nature of the study, there is a probability of error and the impossibility of judgment in some cases. Therefore, it is advisable to conduct a prospective cohort study in the next episode of exposure to influenza because of a probability of emerging new strains of infection.

\section{CONCLUSION}

Based on the current observations of higher than the expected mortality rate for seasonal H1N1 influenza, we suspect of an emergence of a new strain of influenza with remarkable changes leading to higher mortality and morbidity. The absence of typical influenza symptoms such as myalgia should not cause a delay in the diagnosis of the infection in cold seasons, since it is possible that this symptom has not been reported by the patients at the time of admission. It is also recommended that in cases of influenza and pneumonia, a possibility of the super infection with Staphylococcus should be considered, and appropriate treatment should be started quickly.

\section{Acknowledgements}

The authors thank the staffs of Ayatollah Rouhani, Shahid Behashti, and Shahid Yahyanejad Hospitals, Babol University of Medical Sciences. Also authors would like to thank Dr. Evangeline Foronda in the Research Administration Department of Babol University of Medical Sciences for the English editing.

\section{Conflict of interest}

None declared. 


\section{References}

1. Bouvier NM, Palese P. The biology of influenza viruses. Vaccine 2008;26 Suppl 4:D49-D53 https://doi.org/10.1016/j.vaccine.2008.07.039

2. Tong S, Zhu X, Li Y, et al. New world bats harbor diverse influenza A viruses. PLoSpathog 2013;9:e1003657.

\section{https://doi.org/10.1371/journal.ppat.1003657}

3. Petrova VN, Russell CA. The evolution of seasonal influenza viruses. Nat Rev Microbiol 2018;16:47. https://doi.org/10.1038/nrmicro.2017.118

4. Clayville LR. Influenza update: a review of currently available vaccines. $\mathrm{P} \& \mathrm{~T}$ : a peer-reviewed $\mathrm{J}$ Formulary Manage 2011;36:659-84

5. Wilhelm M. Influenza in older patients: a call to action and recent updates for vaccinations. Am J Managed Care 2018;24:S15-S24

6. Ghebrehewet $S$, MacPherson P, Ho A. Influenza. BMJ 2016;355.

https://doi.org/10.1136/bmj.i6258

7. Soleimani G, Akbarpour M. Clinical presentation of novel influenza a $(\mathrm{h}(1) \mathrm{n}(1))$ in hospitalized children. Iran J Pediatr 2011;21:215-9

8. Dandagi GL, Byahatti SM. An insight into the swineinfluenza A (H1N1) virus infection in humans. Lung India 2011;28:34-8.

https://doi.org/10.4103/0970-2113.76299

9. Sullivan SJ, Jacobson RM, Dowdle WR, Poland GA. 2009 H1N1 influenza. Mayo Clinic proceedings 2010;85:64-76.

https://doi.org/10.4065/mcp.2009.0588

10. Lee H-Y, Oh M-N, Park Y-S, Chu C, Son T-J. Public Health Crisis Preparedness and Response in Korea. Osong Public Health Res Perspect 2013;4:278-84. https://doi.org/10.1016/j.phrp.2013.09.008
11. Gooya MM, Soroush M, Mokhtari-Azad T, et al. Influenza A (H1N1) pandemic in Iran: report of first confirmed cases from June to November 2009. Arch Iran Med 2010;13

12. Cheng VCC, To KKW, Tse H, Hung IFN, Yuen K-Y. Two years after pandemic influenza A/2009/H1N1: what have we learned? Clin Microbiol Rev 2012;25: 223-63.

\section{https://doi.org/10.1128/CMR.05012-11}

13. Zhang AJX, To KKW, Tse H, et al. High incidence of severe influenza among individuals over 50 years of age. ClinVaccine Immunol 2011;18:1918-24.

https://doi.org/10.1128/CVI.05357-11

14. Louie JK, Jean C, Acosta M, Samuel MC, Matyas BT, Schechter R. A Review of Adult Mortality Due to 2009 Pandemic (H1N1) Influenza A in California. PLOS ONE 2011;6:e18221. https://doi.org/10.1371/journal.pone.0018221

15. Khiabanian H, Farrell GM, St George K, Rabadan R. Differences in patient age distribution between influenza A subtypes. PloS one 2009;4:e6832-e. https://doi.org/10.1371/journal.pone.0006832

16. Kudo K, Manabe T, Izumi S, et al. Markers of Disease Severity in Patients with Spanish Influenza in the Japanese Armed Forces, 1919-1920. Emerg Infect Dis 2017;23:662-4.

https://doi.org/10.3201/eid2304.152097

17. Mata-Marín LA, Mata-Marín JA, Vásquez-Mota VC, et al. Risk factors associated with mortality in patients infected with influenza A/H1N1 in Mexico. BMC Res Notes 2015;8:1-5.

https://doi.org/10.1186/s13104-015-1349-8

18. Murphy R, Fragaszy EB, Hayward AC, WarrenGash C. Investigating obesity as a risk factor for influenza-like illness during the 2009 H1N1 influenza pandemic using the Health Survey for England. Influenza Other Respir Viruses 2017;11:6673. 
Original article

https://doi.org/10.1111/irv.12420

19. Morris DE, Cleary DW, Clarke SC. Secondary Bacterial Infections Associated with Influenza Pandemics. Front Microbiol 2017;8:1-17.

https://doi.org/10.3389/fmicb.2017.01041 


\title{
Ishodi lečenja bolesnika sa konačnom dijagnozom infekcije virusom gripa H1N1 primljenih u bolnice Univerziteta medicinskih nauka u Babolu u periodu 2015 - 2016
}

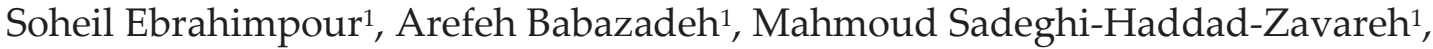 \\ Masomeh Bayani1 ${ }^{1}$ Veneela Krishna Rekha Vasigala², Mostafa Javanian ${ }^{1}$ \\ ${ }^{1}$ Univerzitet medicinskih nauka u Babolu, Babol, Iran, Istraživački centar za infektione i tropske bolesti, \\ Zdraustveni istraživački institut \\ ${ }^{2}$ Univerzitet zdravstvenih nauka dr NTR, Medicinski fakultet Rangaraja, Kakinada, Indija
}

\section{SAŽETAK}

Sa ciljem analiziranja kliničkih manifestacija $\mathbf{i}$ ishoda infekcije virusom gripa, sagledali smo simptome potvrđenih slučajeva infekcije virusom gripa H1N1 $i$ ishode lečenja bolesnika koji su primljeni $u$ bolnice Univerziteta medicinskih nauka u Babolu, u periodu 2015 - 2016.

Ova deskriptivna studija preseka uključila je bolesnike sa dijagnozom bolesti sličnoj gripu, kojisu primljeni u bolnice Univerziteta medicinskih nauka u Babolu, u periodu 2015 - 2016. Za dijagnostikovanje infekcija izazvanih virusom gripa A H1N1 primenjena je reverzna lančana reakcija polimeraze (RT-PCR) na uzorku nazofaringijalnih briseva uzetih od bolesnika.

U ovoj studiji učestvovalo je 123 bolesnika sa dijagnozom bolesti sličnoj gripu. Rezultat reverzne lančane reakcije polimeraze bio je pozitivan kod $47,2 \%$ bolesnika. Simptomi poput produktivnog kašlja (35,3\%), upaljenog grla $(51,4 \%)$, glavobolje $(50 \%)$, dispnoze $(53,2 \%)$ upoređivani su kod PCR + H1N1 potvrđenih slučajeva i slučajeva sa negativnim nalazom na virus gripa H1N1. Među slučajevima sa potvrđenom dijagnozom virusa gripa $\mathrm{H1N1}$, 48,3\% bolesnika primljeno je na odeljenje intenzivne nege zbog ozbiljnosti bolesti, dok je $20.7 \%$ bolesnika preminulo čak i nakon primanja terapije u trajanju od nekoliko dana. Među inficiranim bolesnicima, bilo je 20 trudnica od kojih je tri umrlo. Mortalitet je zabeležen uglavnom u starosnoj grupi preko 50 godina (39\%) ( $p=0,03$ ). Mijalgija je bila značajno manje prisutna u grupi sa_mortalitetom u poređenju sa ostalim starosnim grupama $(6,5 \%$ prema $93,5 \%)(p=0,005)$. Stopa mortaliteta bolesnika koji su primili vankomicin bila je značajno niža $(40 \%)(p=0,01)$. U grupi sa mortalitetom učestalost bolesnika sa nivoima kreatinina preko $1,5 \mathrm{mg} / \mathrm{dL}$ bila je značajano viša nego kod bolesnika koji su se oporavili. Prosečno trajanje hospitalizacije u grupi sa mortalitetom bilo je značajno duže u poređenju sa grupom bolesnika koji su se oporavili (11,1 dana i 6,3 dana) $(p=0,02)$.

Ova studija prikazala je stopu mortaliteta koja je bila iznad očekivane u poređenju sa prethodnim sezonama. Rezultati ove studije ukazuju da odsustvo simptoma tipičnih za grip, poput mijalgije, ne bi trebalo da bude razlog za odlaganje dijagnoze ove infekcije u hladnom periodu.

Ključne reči: virus influence A H1N1, ishod, reverzna lančana reakcija polimeraze 